\title{
LUT
}

University

\section{Why invest in green technologies? Sustainability engagement among small businesses}

Saunila Minna, Rantala Tero, Ukko Juhani, Havukainen Jouni

This is a Post-print version of a publication

published by Taylor \& Francis

in Technology Analysis \& Strategic Management

DOI: $10.1080 / 09537325.2018 .1542671$

Copyright of the original publication: (c) 2018 Informa UK Limited

Please cite the publication as follows:

Saunila, M., Rantala, T., Ukko, J., Havukainen, J. (2018). Why invest in green technologies? Sustainability engagement among small businesses. Technology Analysis \& Strategic Management. DOI: 10.1080/09537325.2018.1542671 


\title{
Why invest in green technologies? Sustainability engagement among
}

\section{small businesses}

\author{
This study examines the links between sustainability engagement and green \\ technology investments. Using data on 139 Finnish small businesses, the results \\ show a positive relationship between the two. The sustainability engagement of \\ small businesses affects their interest in investing in green technology. However, \\ engagement in environmental sustainability does not seem to be the main \\ motivator behind green technology investments. The results of the mediation \\ analysis show that when investing in green technologies, companies do not \\ consider environmental sustainability as a main value but as a way of achieving \\ social and economic value.
}

Keywords: sustainability; green technology; engagement, sustainable development

\section{Introduction}

As sustainability is widely seen as a major driver of technology and innovation, it has been the focus of both research and practice. Prior research has investigated the connection between sustainability engagement and technology investments (Dangelico and Pujari, 2010; Liu et al., 2011; Almeida and Melo, 2017). While both large and small businesses can engage in sustainability initiatives, small businesses are usually more resource constrained (Wolff and Pett, 2006), which affects their urge to invest in green technologies. Thus, small companies must pay attention to multiple sustainability dimensions as enablers of technology investments. Previous research has identified the drivers facilitating green technology investments; these include environmental regulations (Cai and Zhou, 2014; Zailani et al., 2015; Hojnik and Ruzzier, 2016), environmental commitment (Dangelico and Pujari, 2010; Chang and Chen, 2013; Chang, 2016), customer pressure (Horbach et al., 2012; Leenders and Chandra, 2013; 
Huang et al., 2016), managerial concerns (Qi et al., 2010; Huang et al., 2016), and cost savings (Horbach et al., 2012; Horbach et al., 2013; Hojnik and Ruzzier, 2016).

However, there is a lack of research addressing the linkage between sustainability engagement and green technology investments. Some important lines of research deal with the three dimensions of sustainability-environmental, social, and economic (e.g., Kesidou and Demirel, 2012; Boons and Lüdeke-Freund, 2013; Lozano, 2015)—but articles dealing with all three dimensions of sustainability engagement simultaneously in the context of small businesses are scarce (Bos-Brouwers, 2010).

Even though green technology investment is assumed to have positive environmental and economic effects, previous studies of the possible links between firm performance and the application of green technology have generally produced mixed results (Xia et al., 2015). Zhu et al. (2008) stated that green technology selection is a complicated decision-making process that involves planning, evaluating, and adopting a variety of technology options, all in the hope of meeting stakeholder expectations (Xia et al., 2015). In addition, discussions of the integration of sustainability engagement into green technology investments in the context of small businesses are lacking (Cuerva et al., 2014).

Accordingly, this study will examine the possible links between sustainability engagement and green technology investments among small businesses. The empirical component of this research is based on survey data from 139 small businesses operating in the Finnish horse industry. Among these horse industry operators, urbanization has caused challenges regarding sustainability and the environment, such as hygiene and manure-handling problems. As a result, new types of technologies seeking to solve these problems have continuously evolved. Thus, the less studied context of horse 
industry operators provides an interesting and important context for exploring the reasons behind green technology investments.

The structure of the study is as follows: Section 2 explains the conceptual framework of the study, while Section 3 presents the hypothesis development. Section 4 discusses the survey-based approach used as the methodology to identify the links between sustainability engagement and green technology investments, which are presented in Section 5. Section 6 tackles the factors that drive small businesses to engage in green technology investments. Finally, Section 7 presents the conclusions for research and practice, as well as the limitations of the study and further research directions.

\section{Conceptual framework}

\section{Sustainability engagement}

Sustainability engagement can be approached through the widely recognized three dimensions of sustainability: environmental, social, and economic (e.g., Brundtland, 1987; Choi and Ng, 2011; Khan et al., 2016; Almeida and Melo, 2017). Environmental sustainability engagement builds on the assumption that humans live within the boundaries of the physical and biological environment, which serves as the origin of life and as a disposal for waste (Goodland and Daly, 1996; Morelli, 2011). Environmental sustainability focuses on green technologies and innovations targeting the efficient use of resources as well as the simultaneous enhancement of ecological activities and productivity (Galdeano-Gómez et al., 2013; Khan et al., 2016). These types of technologies focus on reducing negative environmental impacts (e.g., those caused by waste management), exploiting ecological processes (e.g., nutrient recycling), and enhancing commitment to sustainable solutions (Pretty et al., 2011; Delai and 
Takahashi, 2011; Galdeano-Gómez et al., 2013). Additionally, environmental commitment boosts the adoption of different sustainable solutions such as technologies targeted at saving energy, preventing pollution, recycling waste, and managing the company's environmental friendliness (Chen et al., 2006).

Social sustainability refers to complementing joint social capital, such as through the participation of communities and through a strong civil society (Goodland and Daly, 1996). Engagement in social sustainability includes the company's balancing of human needs (both societal and individual), economic welfare, and nature's capacity (Choi and Ng, 2011; Khan et al., 2016). Social sustainability engagement takes into account productivity and competitiveness but also honors the environment while ensuring human development, job creation, as well as health and safety (GaldeanoGómez et al., 2013; Khan et al., 2016). Training of employees can engage employees to adjust their actions to be more environmentally sustainable (Huang et al., 2016). Also, a company's internal flow of information drives the adoption of sustainable solutions (Del Río et al., 2015).

Economic sustainability is "the maintenance of capital." It focuses on the monetary value of things. Including environmental value in such measurements is difficult, but the costs of environmental externalities are also included (Goodland and Daly, 1996). Engagement in economic sustainability includes resources (exhaustible and renewable) that contribute to production processes, and it is formed by profits, costs, and new business creation, among others (e.g., Mamede and Gomes, 2014; Svensson and Wagner, 2015). 


\section{Green technology investment}

The terms "innovation" and "sustainability" have been synthesized (Franceschini et al., 2016), deriving four main concepts: environmental innovation, green innovation, ecoinnovation, and sustainable innovation (Schiederig et al., 2012). Previous studies have suggested that these expressions are interchangeable (Hojnik and Ruzzier, 2016), although Schiederig et al. (2012) found that sustainable innovation includes both social and ecological dimensions. While Franceschini et al. (2016) demonstrated overlaps between the concepts of environmental innovation and eco-innovation, their study, as well as that of Charter and Clark (2007), distinguished between these two expressions. Franceschini et al. (2016) stated that eco-innovation refers to environmental and economic sustainability, whereas sustainable innovation also addresses ethical and social aspects. Green innovation is heavily connected to management and competition goals (Franceschini et al., 2016). Albort-Morant et al. (2016) presented two main benefits of green innovation: The first one is related to the commercial rewards received when creating environmentally friendly products, and the second one is related to financial value. Albort-Morant et al. viewed green innovation as a strategic need for companies because it provides a great opportunity to meet customers' needs without causing environmental harm. Chang and Chen (2013) concluded that green innovation is a crucial contributor to business management, which may, in turn, provide a competitive advantage.

To sum up, the traditional definition of innovation refers to the process of generating new products, services, processes, and business models in creating a competitive advantage (Ettlie and Reza, 1992; Baregheh et al., 2009; Saunila et al., 2012; Saunila, 2017). Although innovation in relation to sustainable development emphasizes societal aspects (Berkhout, 2006; Schot and Geels, 2008), this study 
concentrates on technology-oriented view of innovation. Green innovation means the development of new products, services, processes, or management systems that assist in handling environmental problems (Li et al., 2017). Our study defines "green innovation" in a similar manner as Chen et al. (2006) and conceptualizes it as hardware or software connected with products or processes, including innovation in technologies that relate to waste recycling, energy saving, green product designs, pollution prevention, or environmental management (Chen et al., 2006; Chen, 2008). Green technology investment means spending resources such as money or knowledge in acquiring and deploying such technology.

\section{Hypothesis development}

Understanding the drivers of different sustainable solutions is important in answering society's call for companies to invest in technologies that will resolve the current sustainability challenges (Almeida et al., 2013; Lozano et al., 2013). Boons and LüdekeFreund (2013) argued that when considering the sustainability of the value proposition, a balance should be found between optimal product performance (e.g., low cost and convenience) and enhanced environmental and social effects (e.g., better working conditions). Prior research has identified some factors that motivate companies toward green innovations, such as environmental regulations (Cai and Zhou, 2014; Zailani et al., 2015; Hojnik and Ruzzier, 2016), environmental commitment (Dangelico and Pujari, 2010; Chang and Chen, 2013; Chang, 2016), customer pressure (Horbach et al., 2012; Leenders and Chandra, 2013; Huang et al., 2016), managerial concerns (Qi et al., 2010; Huang et al., 2016), and cost savings (Horbach et al., 2012; Horbach et al., 2013; Hojnik and Ruzzier, 2016). The hypotheses presented in the next sections were formed based on previous research. 


\section{Environmental sustainability and green technology investment}

Environmental commitment drives green technology investments, which refer to technologies for assisting waste recycling, pollution prevention, and energy savings (Chen et al., 2006). These types of technologies focus on reducing negative environmental impacts (e.g., those caused by waste management), harnessing ecological processes (e.g., nutrient recycling), and enhancing commitment to environmental solutions (Pretty et al., 2011; Delai and Takahashi, 2011; Galdeano-Gómez et al., 2013). In response to current environmental challenges, a commitment to the environment can assist companies in their attempts to meet their environmental goals, such as by investing in green technology (Chang and Chen, 2013). In addition to the challenges caused by major environmental changes, environmental regulations have also motivated companies toward green technology investments. Government measures that drive sustainable development include policies enacted in a community, integral legislation, and political support for development (Mamede and Gomes, 2014; Lozano, 2015). Even though one motivation for green technology investment might be related to compliance with regulations, Dangelico and Pujari (2010) revealed that environmental regulations do not just represent constraints or regulatory compliance but also offer opportunities for risk minimization, preservation of revenues and reputation, or new business creation.

Based on the previous studies presented above, engagement in environmental sustainability likely leads to an intention to invest in green technologies. Thus, the first hypothesis is as follows:

H1: Environmental sustainability influences green technology investments. 


\section{Social sustainability as a mediator}

Managerial concern has also been shown to be a motivator for green technology investment. Qi et al. (2010) observed that the adoption of green practices seems to be primarily driven by managerial concern. Chen (2008) used a definition of green innovation (Chen et al., 2006) that includes innovation in technologies. Chen (2008) further discovered that companies' green process and green product innovation performance can be enhanced by collective learning and capabilities related to environmental management and green innovation. Thus, according to Huang et al. (2016), the flow of information and a managerial commitment to employee training can be seen as crucial drivers of green innovation. Moreover, Chang and Chen (2013) stated that green innovation plays an important part in business management; companies can enhance their performance, leverage competitive advantage, and create value through efficient management. Hottenrott et al. (2016) argued that the adoption of green technologies might be costly and may even reduce the productivity of companies; however, if green technology adoption can be accompanied by organizational changes that allow a more comprehensive and efficient use of the adopted technology, then the productivity-reducing effect of green technology adoption might be diminished or even reverted.

In addition to managerial concern and human capital development, the business climate is undergoing rapid changes in terms of societal expectations from multiple stakeholders (Dangelico and Pujari, 2010). Dangelico and Pajari (2010) added that companies are facing increasing challenges in addressing sustainability issues in order to attract, satisfy, and retain customers. Thus, customer demands are also seen as a motivator for green technology. Kesidou and Demirel (2012) found that the motivation for the adoption of eco-innovations arises from satisfying the minimum societal 
requirements. Scholars have also shown that customers require companies to produce services, products, and processes aiming to reduce energy consumption and waste as well as increase material efficiency (Horbach et al., 2012). Green innovations have also been identified as a strategic need for firms, offering an excellent opportunity to meet the customers' requirements without harming the ecosystem (Albort-Morant et al., 2016).

The points outlined above can be summarized as follows: Engagement in environmental sustainability leads to increased engagement in social sustainability, which, in turn, leads to an intention to invest in green technology. Thus, the second hypothesis is as follows:

H2: Environmental sustainability influences green technology investments through its effect on social sustainability.

\section{Economic sustainability as a mediator}

The economic motivators for green technology investment can be identified through two elements of the economic dimension of sustainability: one related to the economic interests of companies' stakeholders (e.g., cheaper services or products), and the other to companies' own financial performance (e.g., increased income or cost reduction; Sheth et al., 2011). Related to the economic dimension of sustainability, recent studies have proposed that cost savings are drivers of green innovation (e.g., Horbach et al., 2013; Del Río et al., 2015). Del Río et al. (2015) and Hojnik and Ruzzier (2016) further demonstrated that cost savings seem to be drivers of different eco-innovations as well as environmental R\&D investments. Horbach et al. (2012) also suggested that cost savings are a reason for reducing material use and energy, pointing to the role of taxation as well as raw material and energy prices as drivers of eco-innovation. In addition to 
possible cost savings, green technology investment can also be motivated by productivity improvement (Hottenrott et al., 2016), which plays an important economic role. Hottenrott et al. (2016) argued that improving productivity by investing in green technology is aimed at enhancing the economic situation of companies. Bloom et al. (2010) found that advanced environmental management is associated with higher productivity.

Based on the previous discussion, engagement in environmental sustainability leads to increased engagement in economic sustainability, which, in turn, leads to the intention to invest in green technology. Thus, the third hypothesis is as follows:

H3: Environmental sustainability influences green technology investments through its effect on economic sustainability.

\section{Research model}

Although green innovation and green technologies have been suggested to reduce environmental externalities and operating costs, studies based on engineering data have reported that seemingly cost-effective green investments have not been undertaken (Grubb, 2014; Knobloch and Mercure, 2016). Baumann et al. (2002) also argued that the application of green technologies seems to be limited in practice. Zhao and Mark (2011) demonstrated that in meeting multidimensional requirements, firms have to make trade-offs between positive and negative effects while adopting sustainable technologies.

In sum, many factors motivate companies to invest in green technologies. Various elements (e.g., managerial concern and environmental regulations) also shape companies' strategies, depending on what factors are emphasized in the companies' business. In this study, sustainability engagement refers to the companies' appreciation 
of the three dimensions of sustainability; it is considered a factor that motivates companies to invest in green technologies. The research model (Figure 1) proposes a positive relationship between sustainability engagement (in terms of environmental sustainability) and green technology investments. The relationship between environmental sustainability and green technology investments is mediated by social and economic factors.

Figure 1. Research model and hypotheses

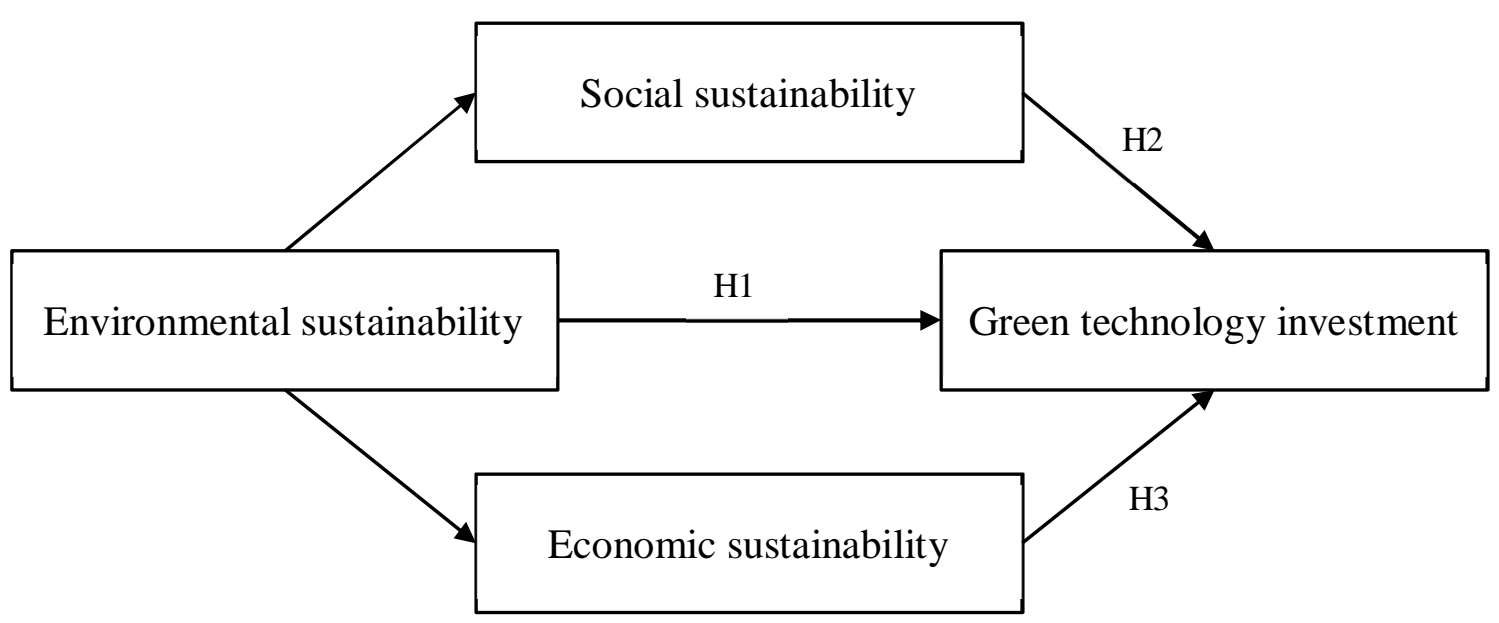

\section{Research methodology}

\section{Sample and data gathering}

In this study, the data were gathered from an online survey questionnaire administered in August and early September 2016. The study population comprises Finnish small businesses operating in the horse industry. The industry is strongly growing and having annual turnover about 720 million euro (Häggblom et al., 2012). Its social and economic importance is shown in employment (15 000 full-time or part-time workers), in the amount of enterprises (16000 stables, of which over 3000 are business oriented), and in the number of people engaged in the sector as a whole (Lunner Kolstrup et al., 2013). These small businesses were selected as the study population due to the existing 
challenges related to sustainability, of which ineffective horse manure handling is one example. The Finnish horse industry has a large amount of underutilized horse manure, and stakeholders such as legislators, technology providers, and horse stables have shown interest in improving the situation (Luostarinen, 2013). The main method of using the horse manure has been to spread it on arable land; other treatment methods such as composting and biogas production have also been used. In the urban areas, away from agricultural land, where most of the horse stables are located, manure handling is causing higher costs and operational harm to other activities. Horse manure was previously handled via waste incineration, which reduced the viability of smallscale combustion plants. According to Luostarinen (2013), the subsidies and financial incentives have been weak in supporting the development of biogas production as a way to fully utilize the biodegradable feedstock. Because of these existing challenges, there has been increased interest in developing new legislation, technology solutions, and service models to alleviate the problem while tapping the underutilized potential of horse manure-for example, as fertilizer products for organic farming or in renewable energy generation. The transition of the horse industry toward a more sustainable business that taps into the underutilized horse manure makes the industry an interesting study subject related to green technology investments.

An email invitation to participate in the survey was sent to 631 small businesses. Of the sent questionnaires, 580 reached the prospective participants, and 51 were sent to email addresses that were no longer valid. Two reminders were sent, and 139 valid responses were received, yielding a response rate of approximately $24 \%$. The demographics were analyzed based on the size of the company and the area of operation where the respondent was employed. Roughly $49 \%$ of the respondents were from micro companies with fewer than 20 horses, while about $48 \%$ were from small companies. 
Around $19 \%$ of the sample represented horse-racing companies, while about $70 \%$ represented horse-riding companies.

\section{Measures}

A survey-based approach was used to test the hypotheses. The survey aimed to collect data on the managerial assessments of the companies' sustainability engagement and green technology investments. A literature review helped in identifying the relevant constructs and previously operationalized scale items (Table 1 shows the items and their sources). All the scales were refined in collaboration with experienced researchers and underwent formal pretests to ensure their content validity.

The dependent variable, green technology investments, was measured with one item, in which the respondents were asked to indicate their willingness to invest in new technologies on a scale of 1-7. Since the focus of the study is on companies' intentions to invest in green technologies, willingness was used as a measure of intention, as suggested by Fishbein and Ajzen (2010). The other study variables, namely environmental, social, and economic sustainability, are presented along with their scales in Table 1. Each variable was measured using four to six items that were adopted from Delai and Takahashi (2011), Mamede and Gomes (2014), Svensson and Wagner (2015), and Khan et al. (2016). The respondents were asked to indicate the significance of each item on a scale of $1-7$.

Two control variables — company size and area of operation-were included in the survey. Company size may influence green technology investments, as companies of different sizes may exhibit different resource deployment levels. In addition, companies in different areas of operation may behave differently in technology investments. Therefore, this study included these variables to control for their potential effects. The 
study measured company size as the number of horses. The dummy variable for the industry type indicates whether a company belongs to the horse-riding or horse-racing category.

Table 1. Study measures

\begin{tabular}{|c|c|c|c|c|c|c|}
\hline Dimension & Items & Source & Loadings & $\alpha$ & CR & AVE \\
\hline \multicolumn{7}{|c|}{$\begin{array}{l}\text { Evaluate the significance of the following items in relation to sus } \\
(1=\text { not at all, } 7=\text { extremely })\end{array}$} \\
\hline $\begin{array}{l}\text { Environmental } \\
\text { sustainability }\end{array}$ & $\begin{array}{l}\text { Nutrient recycling } \\
\text { Commitment to } \\
\text { environment } \\
\text { Waste management } \\
\text { Hygienic factors } \\
\text { Energy consumption } \\
\text { Land occupation }\end{array}$ & $\begin{array}{l}\text { Delai and } \\
\text { Takahashi, } \\
\text { 2011; Khan et } \\
\text { al., } 2016\end{array}$ & $\begin{array}{l}0.832 \\
0.887 \\
0.921 \\
0.865 \\
0.759 \\
0.834\end{array}$ & 0.923 & 0.940 & 0.725 \\
\hline Social & $\begin{array}{l}\text { Ease of material } \\
\text { handling }\end{array}$ & $\begin{array}{l}\text { Delai and } \\
\text { Takahashi, }\end{array}$ & 0.632 & 0.877 & 0.910 & 0.672 \\
\hline sustainability & $\begin{array}{l}\text { Social recognition } \\
\text { Job creation } \\
\text { Health and safety } \\
\text { Human capital } \\
\text { development }\end{array}$ & $\begin{array}{l}\text { 2011; Khan et } \\
\text { al., } 2016\end{array}$ & $\begin{array}{l}0.898 \\
0.832 \\
0.915 \\
0.790\end{array}$ & & & \\
\hline $\begin{array}{l}\text { Economic } \\
\text { sustainability }\end{array}$ & $\begin{array}{l}\text { Cost reduction } \\
\text { Income } \\
\text { Indirect jobs } \\
\text { New business }\end{array}$ & $\begin{array}{l}\text { Delai and } \\
\text { Takahashi, } \\
\text { 2011; } \\
\text { Mamede and } \\
\text { Gomes, 2014; } \\
\text { Svensson and } \\
\text { Wagner, } 2015\end{array}$ & $\begin{array}{l}0.638 \\
0.862 \\
0.871 \\
0.828\end{array}$ & 0.815 & 0.879 & 0.648 \\
\hline
\end{tabular}




\section{Bias}

The possibility of nonresponse bias was investigated by comparing the responses from the first respondents to those of the later respondents, as those that responded last are most likely to reflect nonrespondents (Armstrong and Overton, 1977). No significant differences were found between the respondent groups regarding the study variables, and the variance analysis indicated that the responses were representative of the whole sample. Since the study collected all measures with the same survey instrument, the Harman single-factor test was employed to examine the potential problem of common method variance. Based on principal component analysis, a single factor did not emerge, and one general factor did not account for most of the variance. Thus, common method variance is unlikely to be a serious problem in the data (Podsakoff et al., 2003).

\section{Results}

\section{The measurement model}

The reliability, validity, correlations, and factor loadings of the measurement model are shown in Tables 1 and 2 . The reliability of the scales was tested using composite reliability (CR) and Cronbach's $\alpha$ (Table 1). All the values were higher than 0.7 , suggesting that the scales are reliable (Nunnally, 1967; Hair et al., 1998). Convergent validity was ensured by calculating the average variance extracted (AVE), which should be greater than 0.5 (Hair et al., 1998). The measurement model demonstrated convergent validity (Table 1). All items had loadings greater than 0.6. Finally, the discriminant validity of the constructs was assessed by comparing the square root of the AVE and the correlations between the constructs. Because the square root of the AVE was greater than the correlation between each factor pair (Table 2), the model possesses discriminant validity. This study used variance inflation factors (VIFs) to examine the 
effect of multicollinearity. The highest VIF was 2.43 , which is below the threshold of 5 , suggesting no need for concern with respect to multicollinearity.

Table 2. Results of correlation analyses

\begin{tabular}{llll}
\hline & $\mathbf{1}$ & $\mathbf{2}$ & $\mathbf{3}$ \\
\hline 1 Environmental sustainability & $\mathbf{0 . 8 5 2}$ & & \\
2 Social sustainability & $0.795^{* * *}$ & $\mathbf{0 . 8 2 0}$ & \\
3 Economic sustainability & $0.543^{* * *}$ & $0.671^{* * * *}$ & $\mathbf{0 . 8 0 5}$ \\
4 Green technology investment & $0.214^{*}$ & $0.318^{* * *}$ & $0.353^{* * *}$ \\
& & \\
\hline Note. The diagonal values in bold are the square root of the average variance extracted. & \\
$* * * p \leq .001 . * * p \leq .01 . * p \leq .05$. & &
\end{tabular}

\section{Hypothesis testing}

The data were analyzed using linear regression analyses. The study followed Baron and Kenny's (1986) procedure to analyze the mediating effect of social and economic sustainability on the connection between environmental sustainability and green technology investments. The analysis results presented in Table 3 and summarized in Figure 2 show that all three hypotheses are supported by the data.

First, the control variables were regressed on the dependent variable, green technology investments (Model 1). The results show that neither the company size nor the area of operation affected green technology investments. Following this, the relationship between environmental sustainability and green technology investments was examined. As Model 2 shows, environmental sustainability engagement was significantly related to green technology investments. Thus, Hypothesis 1 is supported.

Second, the effect of environmental sustainability engagement on the mediators, social and economic sustainability engagement, was examined. The results for Models 3 and 5 indicate that environmental sustainability engagement had positive and significant 
effects on social and economic sustainability engagement. The third step was to include the mediators—-social and economic sustainability engagement—in the regression models of environmental sustainability engagement and green technology investments to examine whether this reduced the effect of environmental sustainability engagement to nonsignificance. As Models 4 and 6 show, the coefficients for social and economic sustainability engagement were positive and significant. Furthermore, social and economic sustainability engagement significantly reduced the effect of environmental sustainability engagement on green technology investments, but this relationship was also nonsignificant. The findings indicate that the inclusion of social and economic sustainability engagement weakened the relationship between environmental sustainability engagement and green technology investments. Thus, social and economic sustainability engagement play a mediating role between environmental sustainability engagement and green technology investments, supporting Hypotheses 2 and 3 .

Figure 2. Summary of the results
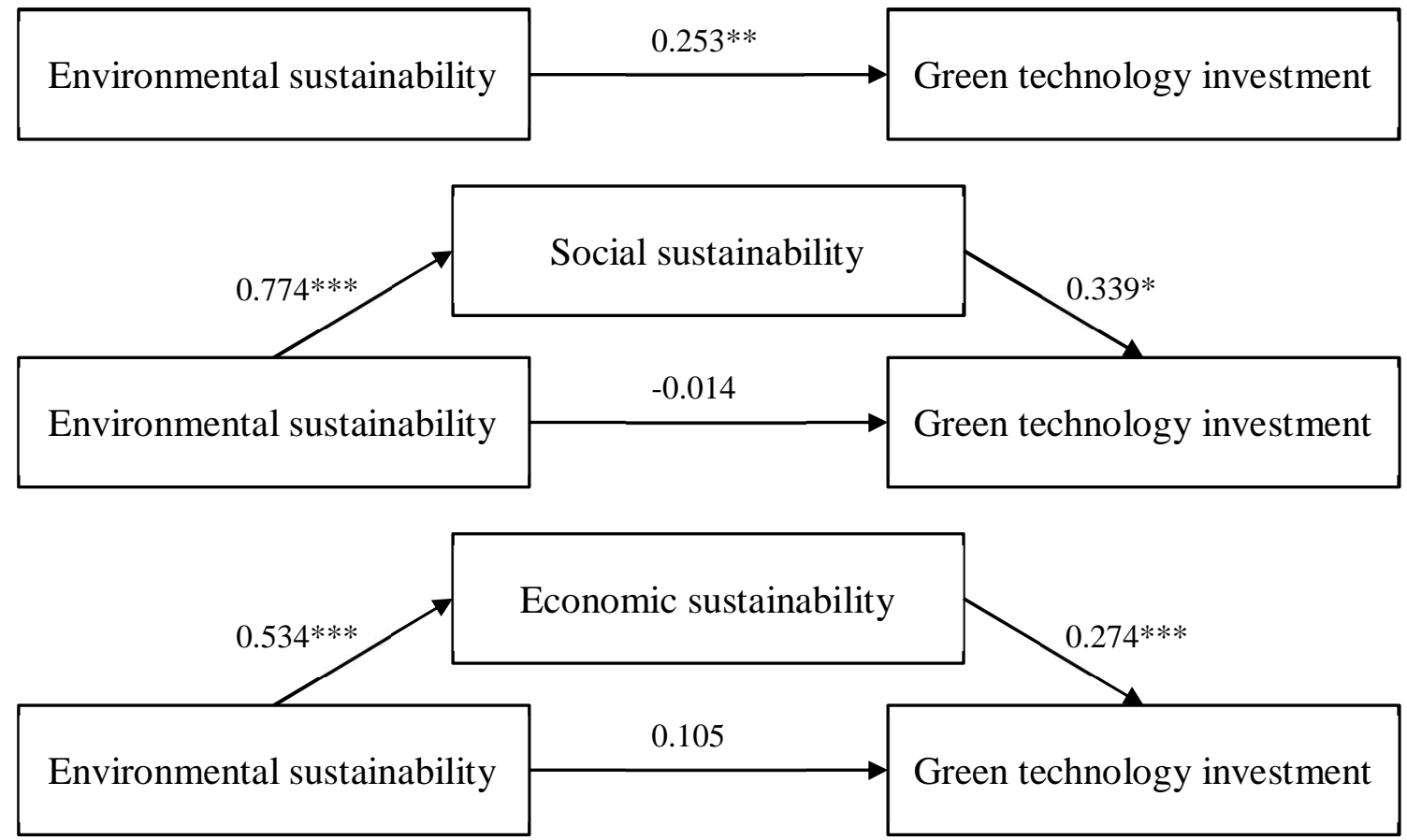

$* * * p \leq .001 . * * p \leq .01 . * p \leq .05$ 
Table 3. Regression analyses for sustainability engagement and green technology investment

\begin{tabular}{|c|c|c|c|c|c|c|c|c|c|}
\hline & $\boldsymbol{\beta}$ & $\mathbf{S E}$ & $\mathbf{S E \beta}$ & $\mathbf{t}$ & $\mathbf{R}$ & $\mathbf{R}^{2}$ & Adj. $\mathbf{R}^{2}$ & $\overline{\mathbf{S E}}$ & $\mathbf{F}$ \\
\hline \multicolumn{10}{|c|}{ Dependent: Green technology investment } \\
\hline 1. Constant & 4.119 & 0.782 & & 5.267 & 0.068 & 0.005 & -0.011 & 2.08318 & 0.290 \\
\hline Company size & -0.247 & 0.337 & -0.067 & -0.733 & & & & & \\
\hline Area of operation & -0.021 & 0.350 & -0.006 & -0.060 & & & & & \\
\hline \multicolumn{10}{|c|}{ Dependent: Green technology investment } \\
\hline 2. Constant & 1.899 & 1.097 & & 1.732 & 0.267 & 0.071 & 0.048 & 2.02558 & $3.040^{*}$ \\
\hline Company size & -0.351 & 0.333 & -0.095 & -1.054 & & & & & \\
\hline Area of operation & 0.055 & 0.345 & 0.014 & 0.160 & & & & & \\
\hline Environmental sustainability & 0.404 & 0.141 & 0.253 & $2.860 * *$ & & & & & \\
\hline \multicolumn{10}{|c|}{ Dependent: Social sustainability } \\
\hline 3. Constant & 2.125 & 0.412 & & 5.163 & 0.773 & 0.598 & 0.588 & 0.76098 & $60.487 * * *$ \\
\hline Company size & -0.079 & 0.123 & -0.038 & -0.643 & & & & & \\
\hline Area of operation & -0.070 & 0.133 & -0.031 & -0.526 & & & & & \\
\hline Environmental sustainability & 0.707 & 0.052 & 0.774 & $13.466 * * *$ & & & & & \\
\hline
\end{tabular}

Dependent: Green technology investment 


\begin{tabular}{|c|c|c|c|c|c|c|c|c|c|}
\hline 4. Constant & 0.494 & 1.197 & & 0.412 & 0.338 & 0.114 & 0.084 & 1.98802 & $3.737 * *$ \\
\hline Company size & -0.275 & 0.329 & -0.075 & -0.837 & & & & & \\
\hline Area of operation & 0.175 & 0.348 & 0.045 & 0.504 & & & & & \\
\hline Environmental sustainability & -0.022 & 0.217 & -0.014 & -0.102 & & & & & \\
\hline Social sustainability & 0.590 & 0.237 & 0.339 & $2.490 *$ & & & & & \\
\hline \multicolumn{10}{|c|}{ Dependent: Economic sustainability } \\
\hline 5. Constant & 3.607 & 0.495 & & 7.289 & 0.534 & 0.285 & 0.268 & 0.92106 & $16.372 * * *$ \\
\hline Company size & -0.058 & 0.149 & -0.030 & -0.386 & & & & & \\
\hline Area of operation & -0.064 & 0.159 & -0.031 & -0.403 & & & & & \\
\hline Environmental sustainability & 0.444 & 0.064 & 0.534 & $6.999 * * *$ & & & & & \\
\hline \multicolumn{10}{|c|}{ Dependent: Green technology investment } \\
\hline 6. Constant & -0.047 & 1.290 & & -0.036 & 0.350 & 0.122 & 0.092 & 1.98003 & $4.076 * *$ \\
\hline Company size & -0.319 & 0.326 & -0.086 & -0.977 & & & & & \\
\hline Area of operation & 0.121 & 0.343 & 0.031 & 0.353 & & & & & \\
\hline Environmental sustainability & 0.169 & 0.162 & 0.105 & 1.040 & & & & & \\
\hline Economic sustainability & 0.527 & 0.195 & 0.274 & $2.705 * *$ & & & & & \\
\hline
\end{tabular}




\section{Discussion}

This study investigating the role of sustainability engagement in green technology investments was triggered by two facets of green technology investments. First, research simultaneously considering all three dimensions of sustainabilityenvironmental, social, and economic — from the perspective of small businesses is scarce. Second, although previous research has broadly discussed green innovation (Albort-Morant et al., 2016; Franceschini et al., 2016), little rigorous empirical testing of what drives small companies to invest in green technologies-one part of green innovation—-has been conducted. Departing from previous research, this study tested the mediation effects of social and economic sustainability on the connection between environmental sustainability and green technology investments.

By testing the theoretical model in terms of the three dimensions of sustainability engagement, interesting results were obtained. We observed an effect of environmental sustainability engagement on green technology investments. The prior literature has found that environmental commitment plays a significant role in reducing the negative environmental effects of business (e.g., in waste management) and harnessing ecological processes (e.g., nutrient recycling; Pretty et al., 2011; Delai and Takahashi, 2011; Galdeano-Gómez et al., 2013). Our findings support the results of these studies. However, the mechanisms of environmental sustainability engagement in relation to real investments in green technologies are less understood.

Our results also show the effect of environmental sustainability on green technology investments under the mediating influence of social and economic sustainability. Thus, the study results imply that when investing in green technologies, small businesses do not consider environmental impact reduction as a main value; rather, environmental sustainability is perceived as a way of achieving social and 
economic value, such as through social recognition, cost reduction, and new business creation. As Horbach et al. (2012) argued, customers want companies to produce products with improved environmental performance and process innovations that increase material efficiency and reduce energy consumption. Similarly, the results of the present study indicate that companies' motivation to invest in green technologies is strengthened if these technologies produce economic and social value in addition to environmental value.

The discovered mediation effect of social sustainability supports the findings of previous studies. According to Huang et al. (2015), employee training can motivate employees to adjust their actions to be more environmentally sustainable. In addition, Del Río et al. (2015) suggested that a company's internal flow of information drives the adoption of sustainable solutions. The results of the current study show that instead of direct effects only, these social aspects of sustainability also have a mediation effect between environmental sustainability and green technology investments.

Finally, the study results show that company size does not affect green technology investments. Despite the common notion that small businesses operate with limited resources (e.g., Wolff and Pett, 2006) such as money and human resources, company size does not seem to affect the intention of small businesses to invest in green technologies. Although these results might be context related and generalization must be done with caution, the findings suggest that if a company is engaged in sustainability in its operations, then its resources are not considered barriers to investing in green technologies.

\section{Conclusion}

In general, the sustainability engagement of small businesses seems to have an impact on their interest in green technology investments. Sustainability engagement affects 
companies' green technology investments regardless of the company size. Engagement in environmental sustainability seems to have a positive effect on green technology investments even though it does not appear to be the main motivator behind green technology investments. The results of the mediation analysis revealed that when investing in green technologies, companies do not consider environmental sustainability as a main value but as a way of achieving social and economic value, such as through social recognition, cost reduction, and new business creation.

\section{Contribution to theory}

This study examined the possible links between sustainability engagement and green technology investments. The sustainability dimensions that drive companies toward investing in green technologies were presented from the triple bottom-line perspective. The study confirmed that the more engaged a company is in environmental sustainability, the more likely the company is to invest in green technology. The results of the mediation analysis indicated that environmental sustainability influences the intention to invest in green technology through its effect on social and economic sustainability. This implies that environmental engagement can also generate financial value. The intention to invest in green technologies can be considered significant when the drivers relate to some tangible resource such as capital. The study also found that company size and operation type do not influence the intention to invest in green technology.

\section{Managerial implications}

This study increases the understanding of how sustainability engagement drives companies toward green technology investments. The study suggests that from the triple bottom-line perspective, each sustainability dimension drives companies toward green 
technology investments in practice. Based on this understanding, green technology providers need to consider all three sustainability dimensions when developing and selling green technologies. Moreover, companies can find a balance between different sustainability dimensions when planning to invest in green technologies, such as biogas plants or services solving manure-handling problems.

\section{Limitations and avenues for future research}

The data were gathered from a specific industry, so generalizing the results to other industries requires further research. However, the horse industry is part of a larger shift toward urbanization. This shift is a reality in a variety of sectors; thus, the results are applicable to a variety of industries outside the horse industry. A further limitation is that the results were gathered from one Northern European country; specific country characteristics need to be considered when applying the results in practice or to further research. Nevertheless, due to similarities in the horse industry among Western countries, the results can be generalized to other Western economies. Other possible limitations of this research are its cross-sectional nature and use of perceptual data. Although perceptual data are extensively used in business studies, this can cause errors when a key informant approach is employed. The key informant approach in this study creates the risk of limitations from common method bias, although the risk of such bias was checked via both statistical and procedural techniques. In addition, these limitations were tempered by considering theoretical arguments rationalizing the analyzed relationships. Future studies could address these limitations.

Further empirical research is required to enhance understanding of the factors affecting green technology investments by small businesses. First, the overall concept of green technology investments includes different types of technologies. Thus, it would be beneficial to explore the drivers of different green technologies. Second, it would be 
interesting to analyze the intention to invest in green technologies based on specific company characteristics such as maturity or internationality.

\section{References}

Albort-Morant, G., Leal-Millán, A., Cepeda-Carrión, G., 2016, "The antecedents of green innovation performance: A model of learning and capabilities". Journal of Business Research, 69(11): 4912-4917.

Almeida, M.F.L.D., Melo, M.A.C.D., 2017, "Sociotechnical regimes, technological innovation and corporate sustainability: from principles to action". Technology Analysis \& Strategic Management, 29(4): 395-413.

Almeida, C.M.V.B., Bonilla, S.H., Giannetti, B.F., Huisingh, D., 2013, "Cleaner Production initiatives and challenges for a sustainable world: An introduction to this special volume". Journal of Cleaner Production, 47: 1-10.

Armstrong, J. S., Overton, T. S., 1977, "Estimating nonresponse bias in mail surveys". Journal of Marketing Research, 396-402.

Baregheh, A., Rowley, J., Sambrook, S. 2009, "Towards a multidisciplinary definition of innovation". Management Decision, 47(8): 1323-1339.

Baron, R. M., Kenny, D.A. 1986, "The moderator-mediator variable distinction in social psychological research: Conceptual, strategic, and statistical considerations". Journal of Personality and Social Psychology, 51(6): 1173.

Baumann, H., Boons, F., Bragd, A., 2002, "Mapping the green product development field: engineering, policy and business perspective". Journal of Cleaner Production, 10(5): 409-425.

Berkhout, F., 2006, "Normative expectations in systems innovation". Technology Analysis \& Strategic Management ,18(3-4): 299-311. 
Bloom, N., Genakos, C., Martin, R., Sadun, R., 2010, "Modern management: good for the environment or just hot air? ". The Economic Journal, 120(544): 551-572.

Boons, F., Lüdeke-Freund, F., 2013, "Business models for sustainable innovation:

State-of-the-art and steps towards a research agenda". Journal of Cleaner Production, 45: 9-19.

Bos-Brouwers, H. E. J., 2010, "Corporate sustainability and innovation in SMEs: evidence of themes and activities in practice". Business Strategy and the Environment, 19(7): 417-435.

Brundtland, G., Khalid, M., Agnelli, S., Al-Athel, S., Chidzero, B., Fadika, L., Hauff, V., Lang, I., Shijun, M., de Botero, M., Singh, M., Okita, S., Others, 1987, Our Common Future ('Brundtland report'). Oxford Paperback Reference. USA: Oxford University Press.

Cai, W.G., Zhou, X.L., 2014, "On the drivers of eco-innovation: empirical evidence from China". Journal of Cleaner Production, 79: 239-248.

Chang, C.H., 2016, "The determinants of green product innovation performance". Corporate Social Responsibility and Environmental Management, 23: 65-76.

Chang, C.H., Chen, Y.S., 2013, "Green organizational identity and green innovation". Management Decision, 51(5): 1056-1070.

Charter, M., Clark, T., 2007, Sustainable Innovation: Key Conclusions from Sustainable Innovation Conferences 2003-2006. The Centre for Sustainable Design, University College for the Creative Arts.

Chen, Y.S., 2008, "The driver of green innovation and green image-green core competence". Journal of Business Ethics, 81(3): 531-543.

Chen, Y.S., Lai, S.B., Wen, C.T., 2006, "The influence of green innovation performance on corporate advantage in Taiwan". Journal of Business Ethics, 67(4): 
331-339.

Choi, S., Ng, A., 2011, "Environmental and economic dimensions of sustainability and price effects on consumer responses". Journal of Business Ethics, 104(2): 269-282.

Cuerva, M.C., Triguero-Cano, Á.,Córcoles, D., 2014, "Drivers of green and non-green innovation: empirical evidence in Low-Tech SMEs". Journal of Cleaner Production, 68: 104-113.

Dangelico, R.M., Pujari, D., 2010, "Mainstreaming green product innovation: Why and how companies integrate environmental sustainability”. Journal of Business Ethics, 95: 471-486.

Delai, I., Takahashi, S., 2011, "Sustainability measurement system: a reference model proposal". Social Responsibility Journal, 7(3): 438-471.

Del Río, P., Romero-Jordán, D., Peñasco, C., 2015, "Analysing firm-specific and typespecific determinants of eco-innovation". Technological and Economic Development of Economy, 1-26.

Ettlie, J.E., Reza, E.M., 1992, "Organizational integration and process innovation". Academy of Management Journal, 35(4): 795-827.

Fishbein, M., Ajzen, I. 2010, Predicting and changing behavior: The reasoned action approach. New York: Taylor \& Francis.

Franceschini, S., Faria, L.G.D., Jurowetzki, R., 2016, "Unveiling scientific communities about sustainability and innovation. A bibliometric journey around sustainable terms". Journal of Cleaner Production, 127: 72-83.

Galdeano-Gómez, E., Aznar-Sánchez, J.A., Pérez-Mesa, J.C., 2013, "Sustainability dimensions related to agricultural-based development: the experience of 50 years of intensive farming in Almería (Spain) ". International Journal of Agricultural Sustainability, 11(2): 125-143. 
Goodland, R., Daly, H., 1996, "Environmental sustainability: universal and nonnegotiable". Ecological Applications, 6(4): 1002-1017.

Grubb, M., 2014, Planetary Economics: Energy, Climate Change and the Three Domains of Sustainable Development. Taylor Francis/Routledge.

Hair, J.F., Black, W.C., Babin, B.J., Anderson, R.E., Tatham, R.L. 1998, Multivariate data analysis. Upper Saddle River, NJ: Prentice hall.

Hojnik, J., Ruzzier, M., 2016, "What drives eco-innovation? A review of an emerging literature". Environmental Innovation and Societal Transitions, 19: 31-41.

Horbach, J., Rammer, C., Rennings, K., 2012, "Determinants of eco-innovations by type of environmental impact-The role of regulatory push/pull, technology push and market pull". Ecological Economics, 78: 112-122.

Horbach, J., Oltra, V., Belin, J., 2013, "Determinants and specificities of ecoinnovations compared to other innovations-an econometric analysis for the French and German industry based on the community innovation survey". Industry and Innovation, 20(6): 523-543.

Hottenrott, H., Rexhäuser, S., Veugelers, R., 2016, "Organisational change and the productivity effects of green technology adoption". Resource and Energy Economics, 43: 172-194.

Huang, X.X., Hu, Z.P., Liu, C.S., Yu, D.J., Yu, L.F., 2016, "The relationships between regulatory and customer pressure, green organizational responses, and green innovation performance". Journal of Cleaner Production, 112: 3423-3433.

Häggblom, M., Rantamäki-Lahtinen, L., Vihinen, H., 2012, "Equine sector comparison between the Netherlands, Sweden and Finland". Equine Life report, MTT Agrifood Research Finland, Jokioinen.

Kesidou, E., Demirel, P., 2012, "On the drivers of eco-innovations: Empirical evidence 
from the UK". Research Policy, 41(5): 862-870.

Khan, E.A., Dewan, M.N.A., Chowdhury, M.H., 2016, "Reflective or formative measurement model of sustainability factor: a three industry comparison". Corporate Ownership and Control Journal, 12(2): 84-94.

Knobloch, F, Mercure, J.-F., 2016, "The behavioural asprect of green technology investments: A general positive model in the context of heterogeneous agents". Environmental Innovation and Societal Transitions, 21: 39-55. Leenders, M.A., Chandra, Y., 2013, "Antecedents and consequences of green innovation in the wine industry: the role of channel structure". Technology Analysis \& Strategic Management, 25(2), 203-218.

Li, D., Zheng, M., Cao, C., Chen, X., Ren, S., Huang, M., 2017, "The impact of legitimacy pressure and corporate profitability on green innovation: Evidence from China top 100". Journal of Cleaner Production, 141: 41-49.

Liu, G.F., Chen, X.L., Riedel, R., Müller, E., 2011, "Green technology foresight on automobile technology in China". Technology Analysis \& Strategic Management, 23(6), 683-696.

Lozano, R., Lukman, R., Lozano, F.J., Huisingh, D., Lambrechts, W., 2013, "Declarations for sustainability in higher education: Becoming better leaders, through addressing the university system". Journal of Cleaner Production, 48: 10-19. Lozano, R., 2015, "A Holistic perspective on corporate sustainability drivers". Corporate Social Responsibility and Environmental Management, 22: 32-44. Lunner Kolstrup, C., Pinzke, S., Löfqvist, L., Järvinen, M., Korpa, V., Paula, L., Kursitis, A., 2013, "Current Status of the Equine Sector in the Central Baltic Region (Finland, Latvia and Sweden) ". Alnarp: Sveriges lantbruksuniversitet. Report series (1654-5427). 
Luostarinen, S. (ed.) (2013). Knowledge Report. Energy Potential of Manure in the Baltic Sea Region: Biogas Potential \& Incentives and Barriers for Implementation. Baltic Forum for Innovative Technologies for Sustainable Manure Management. Mamede, P., Gomes, C.F., 2014, "Corporate Sustainability Measurement in Service Organizations: A Case Study From Portugal". Environmental Quality Management, 23(3): 49-73.

Morelli, J., 2011, "Environmental sustainability: A definition for environmental professionals". Journal of Environmental Sustainability, 1(1): 1-27.

Nunnally, J.C., 1967, Psychometric theory. New York: McGraw-Hill.

Podsakoff, P. M., MacKenzie, S. B., Lee, J. Y., Podsakoff, N. P., 2003, "Common method biases in behavioral research: a critical review of the literature and recommended remedies". Journal of Applied Psychology 88(5): 879.

Pretty, J., Toulmin, C., Williams, S., 2011, "Sustainable intensification in African agriculture". International Journal of Agricultural Sustainability, 9(1): 5-24.

Qi, G.Y., Shen, L.Y., Zeng, S.X., Jorge, O.J., 2010, "The drivers for contractors' green innovation: an industry perspective". Journal of Cleaner Production, 18(14): 1358-1365. Saunila, M., 2017, "Innovation capability in achieving higher performance: perspectives of management and employees". Technology Analysis \& Strategic Management, 29(8): 903-916.

Saunila, M., Ukko, J., Rantanen, H., 2012, Innovation capability and its measurement in Finnish SMEs. In Practice-Based Innovation: Insights, Applications and Policy Implications (pp. 417-435). Springer, Berlin, Heidelberg.

Schot, J., Geels, F. W., 2008, "Strategic niche management and sustainable innovation journeys: theory, findings, research agenda, and policy". Technology analysis \& strategic management, 20(5): 537-554. 
Schiederig, T., Tietze, F., Herstatt, C., 2012, "Green innovation in technology and innovation management: an exploratory literature review". R\&D Management, 42(2): 180-192.

Sheth, J.N., Sethia, N.K., Srinivas, S., 2011, "Mindful consumption: A customer-centric approach to sustainability". Journal of the Academy of Marketing Science, 39(1): 21-39. Svensson, G., Wagner, B., 2015, "Implementing and managing economic, social and environmental efforts of business sustainability". Management of Environmental Quality: An International Journal, 26(2): 195-213.

Wolff, J.A., Pett, T.L., 2006, "Small-firm performance: Modeling the role of product and process improvements". Journal of Small Business Management, 44(2): 268-284. Xia, D., Chen, B., Zheng, Z., 2015, "Relationships among circumstance pressure, green technology selection and firm performance". Journal of Cleaner Production, 106: 487496.

Zailani, S., Govindan, K., Iranmanesh, M., Shaharudin, M.R., Chong, Y.S., 2015, "Green innovation adoption in automotive supply chain: the Malaysian case". Journal of Cleaner Production, 108: 1115-1122.

Zhao, H.W., Mark, P., 2011, "Balancing priorities: decision-making in sustainable supply chain management". Journal of Operations Management, 29: 577-590. Zhu, Q., Sarkis, J., Cordeiro, J.J., Lai, K.H., 2008, "Firm level correlates of emergent green supply chain management practices in Chinese context". OMEGA 36 (4): $571-591$. 